POLIICALECONOMY RESARCH INSTIUIE

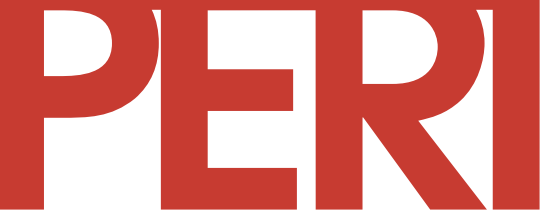

University of Massac husetts Amherst

\title{
Reclaiming Brownfields: From Corporate Liability to Community Asset
}

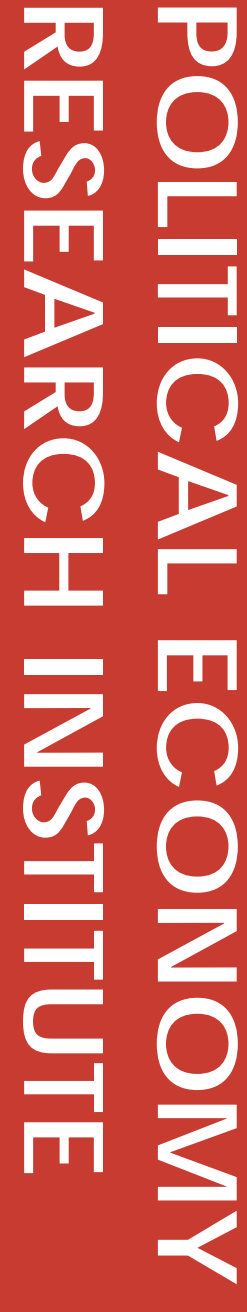

\author{
K.A. Dixon
}

2000

10th floor Thompson Hall

University of Massachusetts

Amherst, MA, 01003-7510

Telephone: (413) 545-6355

Facsimile: (413) 545-2921

Emailperi@ec onsumassedu Whbsite:

hthp:/ wuw.umassedu/ peil/

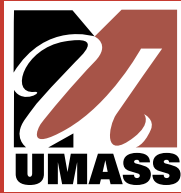




\title{
Reclaiming Brownfields: From Corporate Liability To Community Asset
}

\author{
K. A. Dixon
}

January 2001

Commissioned for the Natural Assets Project Funded by the Ford Foundation

Program on Development, Peacebuilding, and the Environment Political Economy Research Institute (PERI) University of Massachusetts Amherst 


\section{Introduction}

As the U.S. economy continues to march through its longest peacetime economic expansion in history, most urban areas are experiencing healthy levels of economic activity and growth, and many cities are engaging in ambitious redevelopment and revitalization projects. Yet a strong economy does not necessarily translate into income or asset growth for all people. The benefits of the current economic boom have often bypassed impoverished communities in the midst of American cities (Clarke and Gaile 1995, 163).

Many of these impoverished communities are situated in close proximity to polluting industries or the potentially contaminated properties that such industries have left behind as idle or less than fully utilized land. These properties, known as brownfields, can severely impact human health and safety, the environment, property values, and the aesthetic quality of a neighborhood. For many low-income and minority communities, particularly (though not exclusively) in urban areas, such incompatible neighbors are a fact of life.

But they do not have to be. In urban communities throughout the country, citizens are reenvisioning brownfields - previously viewed only as liabilities - as potential community assets. Through creative redevelopment efforts they are transforming these properties into resources which contribute substantial benefits to the surrounding community: a cleaner and safer environment, new jobs, new housing, new commercial or retail space, restored open space, and other public amenities. From a regional perspective, brownfields redevelopment can also help curb suburban sprawl.

Brownfields redevelopment can provide nearby residents-particularly those in lowincome communities - an opportunity to participate democratically in neighborhood revitalization plans, so that outcomes more closely reflect their visions and goals. In such cases, brownfields redevelopment becomes much more than a strategy to clean up and reclaim a contaminated parcel of land. It also becomes a process of community assetbuilding that contributes to the restoration of the physical and social fabric of neighborhoods and the re-creation of vibrant, livable communities.

Throughout the U.S., successful projects have illustrated the potential revitalizing, community-building effects of brownfields redevelopment. This chapter explores lessons gleaned from the last ten years of brownfields redevelopment, focusing particularly on how such efforts can more effectively build the natural asset base of poor communities. It begins with an overview of brownfields redevelopment in the U.S., profiling the problems and benefits of redevelopment, the barriers to such efforts, and the stakeholders involved in redevelopment activities. It then considers strategies by which local 
communities can effectively claim greater ownership of both the decision-making process and the benefits that flow from redevelopment. The chapter concludes with a discussion of cooperative approaches to address two complex issues which confront almost all brownfields projects: liability and financing.

\section{What Are Brownfields?}

The Environmental Protection Agency (EPA) defines brownfields as "abandoned, idled, or under-used industrial and commercial facilities where expansion or redevelopment is complicated by real or perceived environmental contamination." 1 The General Accounting Office estimates that there are over 425,000 brownfields across the nation, posing a threat to public health and the environment, contributing to neighborhood blight, and diminishing local tax revenues $(1987,4)$. Urban and rural communities of all sizes, with diverse industrial histories have contaminated properties that pose redevelopment challenges.

The ownership of brownfields properties is mixed: Some sites are in private hands; others are owned by local, state, or federal governments; still others are orphan sites for which there are no recognized Potentially Responsible Parties (PRP's) to pay for contamination cleanups because such parties no longer exist, are insolvent, or are unknown. Each site has its own industrial history and quality of infrastructure. Site size can vary, from a halfacre former dry cleaning establishment to a 900-acre defunct manufacturing facility. Contamination levels differ too, from none at all to severe contamination. But what all sites have in common is the perception that they are contaminated, and that because of that contamination, redevelopment will be more difficult.

Brownfields sites are typically divided into three broad categories. The first category includes well-located sites that are lightly contaminated and can be redeveloped through private market transactions, without public subsidies or other forms of external intervention. Second, there are sites that are well-located but have moderate to high levels of contamination, or other problematic characteristics such as aging infrastructure or liability issues. These sites thus require public subsidies or other types of external intervention to attract private sector investment. The third category consists of sites so severely contaminated and/or poorly located that a great deal of public support and expenditure will be required to clean and redevelop the property.

Brownfields also can be categorized according to the degree of community ownership of the sites. Ownership here refers not only to actual title to the property, but more generally to the degree to which the local community determines what happens on the site. The continuum of community ownership ranges from situations where the property and the redevelopment process are fully in private external hands (zero percent), to cases where sites are owned and managed by democratic, community-based organizations (100 percent). Public-sector ownership lies between these two poles, its position on the continuum depending on the extent of community participation in the redevelopment process. Even under private corporate ownership, however, the community typically still has some rights with regard to the property: 
Privately-owned land is a community resource, as well as a private one, and local land use laws and zoning ordinances allow for public participation in deciding what is the appropriate use of a piece of land. Local, state, and federal tax breaks and redevelopment assistance only strengthen the argument that the community has a legitimate role to play in land use and development decisions that will affect their environment (Dalton 1998, 4).

Agreements can be crafted that guarantee jobs to local residents, implement various forms of joint land use, and set limits on environmental externalities. Such agreements again represent intermediate points on the community ownership continuum.

Within these categories is a class of brownfields sites that poses a particular challenge: sites "mothballed" by corporate owners who would prefer to leave the sites idle rather than to redevelop them. In these cases the owners do not try to sell, remediate, or redevelop the land. Instead, they hold their land simply to avoid paying cleanup costs: it is less expensive and less of a headache to keep the property dormant or barely operating. To sell or redevelop the mothballed site would expose the owner to a greater risk that others - the public, state regulatory agencies, or the EPA—will discover the site's flaws and possible liabilities. While it may be financially advantageous for corporate owners to mothball these sites, the local community pays the external costs of such inaction, including unabated environmental degradation, related health effects, and the opportunity costs of foregone jobs and lost tax revenues.

\section{Who Benefits From Brownfields Redevelopment?}

A number of stakeholders stand to gain when contaminated urban properties are redeveloped. Local residents benefit from the positive environmental and health effects of reduced air, water, and soil pollution. Residents around the city periphery benefit as land recycling diminishes the need to develop open space, thus combating suburban sprawl. Reclaimed sites provide business and industry with opportunities to locate near customers, potential employees, and transportation routes. Everyone gains from the resulting improvements in urban infrastructure and amenities. Local governments benefit when brownfields parcels return to the tax ledger.

By attracting additional economic activity to the community, brownfields redevelopment can create new job opportunities for area residents. In the report Working on Brownfields, Paula Doogan $(1998,3)$ observes that "the confluence of brownfields, on the one hand, and employment problems, on the other, is striking." The same process that creates brownfields dislocates workers as industries close down or operate minimally. Conversely, the reclamation of these sites increases employment opportunities. Job creation takes place at three stages in the redevelopment process: the assessment and remediation stage, the new construction stage, and the reuse stage. "No brownfields cleanup project exists in a vacuum," she writes. "All are part of economic development and environmental cleanup undertakings that aim to bring renewed economic activity, improved living conditions, and healthier fiscal situations, in short-JOBS-to their 
communities" (Doogan 1998, 3). Since many brownfields sites are located in low-income communities, areas particularly likely to suffer from unemployment and lack of economic opportunities, brownfields redevelopment can create jobs where they are most needed. Depending on the stage of redevelopment and end use of the site, this can include a mix of permanent and temporary jobs with diverse skill-level requirements.

However, not all brownfields projects create permanent jobs, and those that do create jobs do not automatically employ the people who live closest to the site. Unless stakeholders in the redevelopment process are committed to the principle of hiring local residents, employment benefits may go to others. Projects that are committed to local employment are typically those with some degree of community participation and publicsector involvement.

\section{Barriers to Brownfields Redevelopment}

Unfortunately, the multiple benefits of brownfields redevelopment often are blocked by multiple barriers to such activities. The costs to clean up and redevelop brownfields sites are often greater than those for undeveloped open space. An array of factors drives up these costs and, consequently, creates significant barriers to brownfields redevelopment.

First, the fact that brownfields sites are perceived to be contaminated means that property owners, developers, and lenders fear the liability risks commonly associated with such sites. Under current federal law, liability at contaminated sites-from Superfund sites to the most lightly tainted brownfields - is joint, several, and retroactive. That is, everyone in the chain of title can be held liable for contamination that has already occurred, for future contamination at the site, and for any contamination of neighboring properties. All of these parties could be held responsible for the clean-up cost. The magnitude of liability and its associated costs (including assessment, remediation, third-party damages, and litigation fees) vary from site to site and are contingent not only on the level of contamination, but also on the willingness of the potentially responsible parties to engage in redevelopment activities and on their ability to manage risk.

Steps have been taken at the state and federal levels to allay these fears and to reduce the risk of liability. In 1996, the federal government amended the Comprehensive Environmental Response, Compensation, and Liability Act of 1980 (CERCLA, better known as the Superfund Act) to reduce the liability of institutions that make loans to brownfields redevelopment projects. ${ }^{2}$ States such as New Jersey have established grant and loan funds to assist in the cleanup and redevelopment of contaminated sites. Despite these efforts, however, the risk of liability claims remains a significant barrier to brownfields redevelopment.

Other site characteristics can pose further barriers to redevelopment. Many brownfields sites support aging and obsolete infrastructure unsuitable to modern manufacturing techniques. Frequently, brownfields parcels are too small to support cost-effective redevelopment, and the difficulties associated with land assembly prevent interested parties from forming larger, more viable properties. Locational factors such as limited 
access to transportation routes, a high incidence of crime, neighborhood physical decay, and the insufficient availability of a qualified workforce may also serve to deter redevelopment. Brownfields projects can take a long time to complete, often much longer than conventional development projects. Assessing and remediating a contaminated site, securing the necessary environmental regulatory permits and approvals, and arranging financing can extend the timeline considerably, and time can make or break a redevelopment deal.

Finally, one of the most significant barriers to transforming brownfields liabilities into community assets is the way most stakeholders define "redevelopment." In the context of brownfields, redevelopment generally refers to market-driven commercial or industrial end uses which are expected to generate profits (Mallach 1998, 7). Such use, of course, should be a serious option among the redevelopment possibilities; the results often can significantly benefit low-income communities. But such redevelopment may not always be what communities want or need most. Preferred end uses may include low-income housing, public parks, community gardens, or green houses, the benefits of which cannot be judged simply in terms of the number of jobs and the level of market activity generated. Securing the support and financing for non-revenue-producing end uses such as parks and open space, however, is often highly problematic. Conditions on available funding thus can restrict the ability of communities to implement their own visions of what is best for their neighborhood.

For this reason, some believe that the concept of redevelopment needs to be redefined. Mallach $(1998,8)$ contends that "if brownfields remediation and redevelopment are to take place in urban neighborhoods, federal and state government will have to abandon the market-driven model of redevelopment, and replace it with a model grounded in community benefits." This redefinition would facilitate redevelopment for a wider range of uses that contribute to the asset base of the community.

\section{Who Can Make It Happen? Partnerships for Brownfields Redevelopment}

Despite these formidable barriers, brownfields redevelopment activity has increased substantially in recent years and has gained prominence on the national political agenda. Projects have garnered support from a broad range of stakeholders: federal agencies, state and local governments, community-based organizations, business enterprises, and a scattering of private financial institutions. While each of these actors plays distinctive roles, it is their ability to work together in creative partnerships that can most enhance the possibilities that redevelopment efforts will serve the needs of poor communities.

The Environmental Protection Agency (EPA) has provided national leadership in encouraging brownfields redevelopment, launching a campaign to "prevent, assess, safely clean up and sustainably reuse" brownfields. ${ }^{3}$ The EPA addresses redevelopment issues on several fronts, including financing, liability concerns, and education. The agency offers grants and loans to cities, states, and tribes that are redeveloping a site or working to set up a brownfields program. As part of this program, the EPA requires that applicants notify and actively involve the local community in planning and development decisions. ${ }^{4}$ 
The agency also provides clarification and guidance on liability and cleanup issues, and has instituted a new program to link brownfields projects to job training and workforce development. Finally, the EPA is working in partnership with state governments to develop Voluntary Cleanup Programs (VCPs) to facilitate brownfields redevelopment and to encourage private sector involvement.

Federal support for brownfields redevelopment is not limited to the EPA. The Department of Housing and Urban Development (HUD), the Economic Development Agency, the Department of Transportation, the Department of Energy, and other federal agencies participate in an inter-agency brownfields redevelopment working group coordinated by the EPA. The programs of these agencies augment those of the EPA by providing loans and grants, technical assistance and training, clarification of liability issues, and support for efforts to develop state brownfields programs.

States and municipalities also play important roles in brownfields redevelopment, as will be illustrated in the examples discussed below. State and local programs are particularly important in cases where the sites are small, moderately to highly contaminated, poorly located, or some combination thereof, thus making redevelopment less attractive to private investors. Municipal governments, in particular, can be a source of important technical assistance, financing, and other support that local communities need to engage in complex redevelopment activities.

In addition to federal, state and municipal initiatives, local residents and communitybased organizations have taken leading roles in the redevelopment of brownfields sites in a number of cities, including Pittsburgh, San Diego, Minneapolis, and Birmingham. Private, non-profit community development corporations (CDCs) have been particularly important contributors of planning and organizing expertise to the redevelopment process. The CDC's often wear many hats, simultaneously serving as project managers, financial intermediaries, developers, and community organizers. They often take on projects the business sector avoids, and fill gaps left by local government and federal initiatives. Community support and participation are often hallmarks of brownfields projects with a significant degree of CDC leadership, playing a crucial role in the successful completion.

Finally, private businesses and financial institutions are usually key players in successful brownfields redevelopment. Often they provide a major portion of the investment which generates jobs and stimulates the local economy. Not all brownfields projects lend themselves to high degrees of community decision-making, and not all communities have the wherewithal to pursue such ownership strategies. However, strictly private development projects-in which one private owner sells the property to another private owner without public sector involvement-are less likely to present opportunities for community involvement.

The partnerships forged among public agencies, community-based organizations, and private firms during the development process are of fundamental importance in increasing the chances of successful brownfields redevelopment (Pepper 1996; Van Horn 
1999). Establishing effective working relationships among all actors reduces the risk that the transfer and subsequent redevelopment of the asset will be derailed by one disgruntled stakeholder, or slowed by the inability to reach consensus. Such partnerships are neither easy to form nor easy to maintain, however, since the primary interests among the different stakeholders are often contradictory. "The durability of partnerships for initiating and coordinating urban social change," Jezierski (1995, 300) observes, "requires constant efforts to institutionalize conflicting interests and construct legitimacy for development policy and for the partnership itself." Despite the difficulties of reconciling stakeholder interests, the effort required to build and maintain effective partnerships is a wise investment.

\section{Building Brownfields Assets In the Hands of the Community}

In financial markets one party's liability is another party's asset. For example, in a home mortgage the liability on the homeowner's balance sheet corresponds to an asset on the bank's balance sheet. Similarly, if a brownfields site is a potential or actual liability to its current owner, then it represents an asset to other parties, including local residents who could sue for damages and/or force the owner to clean up the site. This is not to suggest that proximity to contaminated sites is desirable for a community. But once the environmental damage has been done, the community has a claim for just compensation and/or redress of the injury it has suffered. In this admittedly unconventional sense, brownfields are latent community assets. The issue is how to transform them into performing assets that provide flows of benefits to the surrounding community.

The extent to which low-income communities are able to convert these assets and obtain their benefits is contingent, in large part, on how far they are able to move along the ownership rights continuum towards increased participation in and control of the redevelopment process. The spectrum of community participation ranges from simple public notification, to varying degrees of direct input into decisions on issues such as hiring and workforce development planning, to management of the redevelopment process, to ownership of the reclaimed site itself.

\section{Community notification}

Many municipalities have community notification requirements for developers undertaking brownfields projects. These may include public hearings which community residents can attend to learn about the project and the job opportunities redevelopment will generate, and to voice concerns. While valuable, community notification itself does not facilitate truly shared decision-making power, and it often occurs too late in the redevelopment process to allow local residents to participate meaningfully.

\section{Community participation in developing hiring goals}

From the outset, project stakeholders and local residents can work with future tenants of the redeveloped site to anticipate the number of workers who will be hired and the job skills they will need. Federal, state, and local employment and training programs can then 
be coordinated to provide training and employment related assistance in such areas as resume writing and interview skills. When site redevelopment is completed, local residents are then better equipped with the necessary skills to compete successfully for jobs. Such training efforts can be complemented by municipal tax incentives or other policies to encourage the hiring of local residents.

Such a strategy is being employed at the North Birmingham Industrial Redevelopment Project in Birmingham, Alabama. ${ }^{5}$ The city and a number of community organizations are coordinating the redevelopment of this 900-acre site, which includes active industrial facilities, derelict and abandoned buildings, dilapidated housing, and vacant space. The site is well-located, being close to the center of town, the Birmingham International Airport, and several interstate highways and rail lines. A mixed-use redevelopment is planned, consisting of new light industrial and commercial uses, improved existing industry, community amenities, residential areas, and public open space.

The North Birmingham project was among the first to be designated an EPA brownfields pilot project. The $\$ 200,000$ pilot grant was used to set up the Birmingham Environmental Clearinghouse, a non-profit organization designed to conduct community outreach and education on environmental issues, which helped to form the North Birmingham Economic Revitalization Corporation to coordinate the economic redevelopment site.

A primary focus of the project is job creation, and the redevelopment is expected to create over 2000 additional jobs at the site. Project coordinators are working to ensure that primarily local residents are hired for these jobs. The site is within a state Enterprise Zone where tax benefits encourage local hiring. In addition, community organizers and local residents intend to work with each potential tenant to ascertain how many employees and what types of skills the company will require so that local people can be trained beforehand. Job training and assistance programs for local residents are being established.

These efforts have already scored some success. The first three companies to locate on the site have created approximately 200 jobs, more than half of them filled by local residents. If assets are broadly understood as claims on future income streams, such employment gains can be considered a form of asset-building. In this case, however, there is no formal agreement between the employers and the local community which guarantees local residents access to the new jobs. Thus, their claim on the employment "asset" remains tenuous.

Taking community input a step further, some brownfields projects have included formal agreements with end users that commit the latter to a certain percentage of local hiring. Although they still need proper training and skills, local residents find themselves with a leg up in the hiring process. A good example is the Quarry Retail Project in Minneapolis, which not only removed a significant environmental hazard from the low-income neighborhood and brought in much-needed retail services, but also increased the number of jobs on the site from less than 250 to around 2000. Recognizing the complexity of the project and being persuaded by government offers of financial and technical assistance 
and tax incentives, the developer of the site agreed to a cooperative working relationship with both the city of Minneapolis and a neighborhood task force representing local residents. ${ }^{6}$ Working within this cooperative arrangement, the city set project employment goals to ensure that a fair portion of the new jobs went to local and minority residents. The project surpassed its twenty percent minority hiring goal, achieving a level of twenty-five percent. Both the developer and two of the project's largest tenants (Target and Rainbow Foods) pledged to hire locally (Pepper 1997, 76). While the city provides some funds for training programs, many of the retailers in the new development provide job training to potential employees. In addition, retailers have attended community meetings to announce job openings and take applications for employment.

This experience has been replicated and strengthened elsewhere. Many private firms receive public subsidies to redevelop brownfields sites. Such subsidy arrangements can include a condition that the firm or developer agree to hire local residents, perhaps in some cases with priority given to residents who have been unemployed for long periods. Several cities, including San Francisco, Berkeley, Boston and Jersey City have used this strategy (Krumholz 1995). In the event that a firm or developer fails to live up to its performance commitments, it is required to reimburse the city for the benefits it received, plus interest (Krumholz 1995, 181).

\section{More than jobs: owning the redevelopment process}

Sherraden $(1991,99)$ defines assets as "rights or claims related to property, concrete or abstract." If we continue to take a broad view of asset-building, community participation in the redevelopment process, if sufficiently meaningful and intensive, can approach asset ownership. In such cases the community does not own the property in the traditional sense, but it "owns" the process by which decisions regarding reuse and redevelopment are made. Beyond just securing employment opportunities, low-income residents secure the right to determine the destiny of the place in which they live.

Successful brownfields projects typically are the result of an effective collaborative planning process, involving "a search for voluntary, consensual solutions to environmental problems through joint participation by federal, state, and local agencies; business and industry; environmental groups; other interested nongovernmental organizations; and citizens" (Vig 1999, 382). The case of the LTV Southside Works project in Pittsburgh illustrates such a collaborative approach in which there has been a high degree of community ownership of the decision-making process.

The LTV Steel South Side Works site is a 130-acre parcel of land with approximately one mile of frontage on the south side of the Monongahela River. The site is located centrally within the city of Pittsburgh and is close to most of the city's major areas of employment. The surrounding residential community, known as the Southside, is an attractive, somewhat worn, predominantly blue-collar neighborhood. The residents are a racially diverse mix of older people, many of whom have lived in the neighborhood for many years; young families; and single people. 
Southside has a decades-long history of activism and community advocacy, and the neighborhood supports several community-based organizations. Among these is the Southside Local Development Corporation (SSLDC), a CDC. Out of a community meeting organized by SSLDC in 1985, the South Side Steering Committee was formed to develop long-range strategies for neighborhood redevelopment. Based on the work of this committee, the community decided to create the Southside Planning Forum, an umbrella organization for all neighborhood groups including Southside Community Council, the Southside Business Alliance, SSLDC, and Friends of the Southside Branch Library. The Planning Forum meets monthly and operates by consensus.

When the LTV Steel Southside Works, a steel plant, closed its doors in 1986, the community had the organizational capacity to take a proactive approach to redeveloping the site. LTV Steel itself went to SSLDC to seek advice regarding what to do with their land. Contamination was not all that extensive, but the property nevertheless would have been very difficult to sell on the private market. Over 100 residents took part in a series of community meetings in 1991 to solicit opinions and input. With the help of SSLDC, and with funding from LTV Steel, the community developed a set of ten recommendations regarding redevelopment and end uses of the site.

\section{Recommendations from \\ A Community-Base-Planning Evaluation: LTV Steel's South Side Mill Site}

1) Planning for the site should be consistent with the South Side Neighborhood Plan.

2) The property should be zoned as a Special Planned District to promote flexible development while also assuming maximum public review.

3) Development should not overburden local streets or available public services.

4) There should be a high level of public participation in the redevelopment process.

5) Planning for and development of the site should respond more to long-term objectives than to short-term opportunities.

6) Mixed-use development is encouraged to provide flexibility, respond to market opportunities, assure expeditious development, and ensure variety in keeping with the existing community.

7) Development of the property should be directed to markets that complement rather than duplicate those already existing in the community.

8) Development of the site should be master-planned, paying attention to the outlying parcels to the south of East Carson St. so that development is to scale and in character with its surroundings.

9) The riverfront should be treated as an amenity for public access.

10) Interim uses are strongly discouraged. ${ }^{7}$

These were adopted by the Planning Forum and have served to guide the on-going redevelopment process. In addition, similar recommendations modeled on these have been adopted by other Pittsburgh communities engaged in redevelopment efforts.

Even more importantly, the Southside Planning Forum entered into a legally binding agreement with the Urban Redevelopment Authority (URA), the redevelopment agency 
of the city and eventual site owner, regarding reuse of the site. To ensure community participation in the process, the agreement specified (1) a planning process to include conceptual plans, socio-economic assessment, traffic analysis, market analysis, a master plan, selection of qualified developers, and a final land development plan; (2) a planning team to include representatives from the community, the URA, the city planning office, and other appropriate individuals; and (3) additional measures to promote public participation including the dissemination of information to Planning Forum members, community meetings, and educational sessions; community consensus on the master plan; participation by the planning team at Forum meetings as needed; and financial and technical assistance to enhance the Forum's ability to participate in the process.

This agreement codified the residents' right to take an active leadership role in the redevelopment of the site. It did not guarantee a problem-free project, of course. ${ }^{8}$ There have been, and no doubt will continue to be, bumps along the road as redevelopment of the site continues. It will be several years before the economic impact of the project on the community can be accurately assessed, but what has been accomplished so far is impressive. The plan for the site envisions a mixed-use, pedestrian-friendly development to evolve over a number of years. The site will feature more than 300 new housing units, 250,000 square feet for retail space, 180,000 square feet for flexible use, product distribution and entertainment enterprises, and 1.6 million square feet for offices and research and development (Urban Redevelopment Authority 1999, 1). Over 6000 new jobs are expected to be created, and the SSLDC is negotiating with the URA to ensure that a significant portion of these go to local residents. Though the community does not hold title to the property, it has thus gained significant control over the asset by winning the right to help determine the direction of the redevelopment process.

Several factors contributed to the Southside community's ability to move beyond public notification and more limited participation to take a significant degree of ownership of the process. First, the Southside has a history of activism and community participation, and its cadre of community-based groups were already well-established and capable of coordinating community input and decision-making. Second, this project benefited from a public sector that intervened where the private market had failed. LTV Steel had no use for the site and wanted to sell it, but the company could not find a buyer willing to take on a contaminated piece of property. The URA allowed redevelopment to move forward when it stepped in to negotiate a partial liability release with LTV Steel, and subsequently bought, assessed and remediated the site. ${ }^{9}$ Finally, the URA was open to the high level of community involvement in the Southside. "The community was an asset to this project," stated Marc Knezevich of the URA. "Their input was extremely valuable" (Knezevich 1999). The community and the city have formed a partnership that keeps the lines of communication open and provides an on-going forum to address problems as they arise.

Community ownership of the process need not end with the successful completion of the brownfields clean-up and physical rebuilding. The community must ensure that the end uses are appropriately managed and continue to be compatible with the community's redevelopment vision. To this end, Dalton (1998) suggests the use of "Good Neighbor 
Agreements" between communities and the new businesses that occupy the site. Such agreements would require disclosure of how the business will operate and would stipulate the local community's right to inspect the facility. They also could specify measures to guarantee that any contamination left on the site would remain contained, and could set job creation and hiring goals.

\section{Owning the land: The Dudley Street Neighborhood Initiative and the power of eminent domain}

In Boston, one neighborhood has accessed a powerful brownfields redevelopment tool that allowed it to achieve an unprecedented level of community ownership: the power of eminent domain. In the early 1980's, Boston's Dudley Street neighborhood was in serious decline, characterized by high levels of poverty, unemployment, crime, and pollution, and by inadequate public services. Following a rash of arson, more than 20 percent of the lots in the one-and-a-half-square-mile community were vacant (Wallsjasper 1997). Yet the Dudley Street neighborhood was home to a diverse group of African-American, Latino, Cape Verdean, and white citizens who shared a vision of their community beyond the empty lots, dilapidated buildings, and unsafe streets, and who were determined to work together to make it a reality.

The revitalization of the Dudley Street area began in 1984, when local residents came together to form the Dudley Street Neighborhood Initiative (DSNI). DSNI is a nonprofit community-based group whose mission is to "empower Dudley residents to organize, plan for, create and control a vibrant, diverse and high-quality neighborhood in collaboration with community partners" (Dudley Street Neighborhood Initiative 2000). ${ }^{10}$ Working with other civic and church groups, DSNI facilitated a community visioning process to help local residents determine the economic, environmental, and cultural future of the neighborhood. One issue which emerged as a central concern was how to deal with the vacant lots that riddled the neighborhood and served as a barrier to comprehensive revitalization. Residents recognized that the best way to achieve their goals would be to gain control over these assets. The city of Boston had acquired about half of the empty lots through tax delinquency, and it agreed to deed them to DSNI. Private individuals, many of whom were hoping to capitalize on any potential redevelopment of the area, held the remainder of the vacant lots.

Eventually, after several years of court challenges, DSNI won the right to impose eminent domain - a right usually reserved for the public sector or public-sector sponsored agencies, and traditionally not used in favor of low income neighborhoods-throughout a 60 -acre portion of the neighborhood. Armed with this powerful tool, the community was able to assume title to unused land in their neighborhood, and it has redeveloped more than 300 of the 1300 vacant parcels.

\section{Lessons for community organizing}

At the end of the day, it is the local community that will feel the most profound effects, positively or negatively, from brownfields redevelopment. As the cases discussed above 
illustrate, the degree to which communities establish ownership of brownfields assets and gain access to the benefits which flow from them is contingent upon a number of factors, perhaps most importantly their ability to organize and exercise its power vis-à-vis other private and public-sector actors. Communities with a history of activism and organizing usually are best prepared for this challenge. The presence or formation of an effective community-based organization, such as a community development corporation, a citizen task force, or a neighborhood association seems essential to the success of community asset-building efforts. From previous brownfields redevelopment experience, we can glean some of the critical elements of successful community organizing efforts.

The community first must establish a system of decision-making that will facilitate the democratic formulation of both the community's long-term vision of its future and concrete decisions on the redevelopment of specific brownfields sites. A representative steering committee, task force, or planning forum should coordinate community information-sharing, participation, and decision-making. In the case of Dudley Street, for example, the residents have established a 29-seat Board of Directors, made up of twelve residents from each of the area's four main ethnic groups (African-American, Latino, Cape Verdean, White), 2 additional Board-appointed residents, 2 youth, 7 nonprofit agencies, 2 churches, 2 businesses, and 2 CDCs.

Members of the decision-making body must create mechanisms through which all residents have access to the project proceedings and decisions. Ownership of the process must be shared from the beginning. A regular schedule of meetings and discussion forums can provide members of the community with opportunities to hear about options and voice opinions. In North Birmingham, the Greater Birmingham Ministries conducted a door-to-door survey to assess housing needs and gauge resident opinion regarding the neighborhood's strengths and weaknesses. Telephone and mail surveys and focus groups can also be useful. Communication between local residents and their representatives must be consistent, frequent, and two-way.

Through this open process the decision-makers should develop a neighborhood master plan to articulate the community's overall vision and its particular goals for the site. The Neighborhood Plan devised by the Southside community in Pittsburgh is a good example of situating site redevelopment within the larger vision for the community. As Mallach $(1998,4)$ explains,

simply trying to define and carry out the most desirable outcomes with respect to physical and environmental change, without integrating into a community-oriented process that is capable of making that change happen, and sustaining it in the future, is unlikely to be productive, much as it may bring about superficially impressive achievements in the short run. Without a clear view of those outcomes, however, and steady progress toward achievement of the neighborhood's goals, the most carefully conceived and broadly participatory process will sooner or later disintegrate. 
A Neighborhood Plan that codifies the community's intentions will remind all stakeholders - the community, the municipality, the developer, the end users - what the project goals are.

Much is required to keep community residents actively and positively involved over the long haul. Obviously, not every member of the community will participate in this process, and not everyone who does participate will get everything he or she wants. There will be disagreements; compromises will be required. Relationships among stakeholders must be continually refreshed, strengthened, and possibly renegotiated as the redevelopment effort progresses. "People get impatient," remarked one community leader actively involved in the North Birmingham Industrial Redevelopment Project. "The size of the site is sometimes overwhelming, and we need to let people know that improvements to one area benefit everyone" (Davis 1999).

\section{Resolving the Liability Issue}

One of the primary reasons some sites are mothballed, instead of being sold or redeveloped, is because their corporate owners fear being held liable for cleanup costs and known or potential damages from contamination. At the same time, many of these owners likely would be glad to rid themselves of unprofitable properties for which they have no use. If the threat of liability is removed or substantially reduced, the owners of mothballed sites are more likely to accept opportunities to transfer the property to new owners.

From the standpoint of the community, as noted earlier, these liabilities are an important latent asset, one for which the community has, in a very real sense, already paid by bearing the external costs of living near contaminated and abandoned sites. The possibility exists to reduce corporate liability in exchange for some transfer of other asset rights to the community. A reduction of corporate liability need not mean its complete elimination, however. Rather, the options lie along a continuum of burden sharing among three parties: the corporate owner, the community, and the public sector.

One possibility is for the community or its representative entity (a CDC, or some other intermediary), to indemnify the property against legal action, effectively assuming the risk of liability itself. ${ }^{11}$ In exchange, corporate owners donate the land. In this scenario, the community and the corporate owner in effect agree that the "price" of the land equals the value of the liability. There is no intrinsic reason, however, why the two amounts should always coincide. Agreements could also be brokered whereby the corporate owner, in exchange for release from liability, would both donate the title of the land and pay part or all of the cost of remediating the property. This would be possible if the corporate owner's potential liability were significant enough, or if public-sector incentives made the option attractive enough. One incentive for the owner to relinquish title to the property could be an agreement to settle fines the owner might owe for environmental violations. Another could be public sector assistance in securing permits for building elsewhere. 
Depending on the state in which the site is located, the transfer of liability and the costs of remediation of the site can be negotiated through Voluntary Cleanup Programs (VCP's). ${ }^{12}$ Under the guidance of the state VCP, the site can be assessed and remediated to meet appropriate cleanup and health standards. Many states allow for Risk-Based Cleanup Actions whereby the required level of remediation of a parcel depends upon its intended end use. For example, for a site where the intended reuse is housing, cleanup would have to meet more stringent health standards than if manufacturing is the intended use. Upon completion of the cleanup, the original site owner receives written confirmation that they have satisfied state laws and will not be held liable by the state for any future cleanup costs or contamination. The new site owner enters into an agreement with the state indicating they are now the responsible party.

For the corporate owners, this is not a completely risk-free process. Protection from state liability does not protect former and current owners from third-party legal actions. Furthermore, a waiver from state liability does not translate automatically to a waiver from federal liability. In the event that more contamination is discovered in the future, the EPA can hold all former and current owners/operators of the site liable, but so far the agency has been loath to infringe upon state-negotiated cleanup and liability agreements. Hence, the benefits of such a negotiated transfer of property may outweigh the risks. The corporate owner rids itself of a burdensome property, perhaps even garnering some positive public relations, tax deductions, or other benefits in the process, in addition to a reduction in liability risks. The community obtains the property or claims to the benefit flows from it, helping to build the community's natural asset base.

Another way to resolve the liability deadlock is through environmental insurance, used alone or in conjunction with the previous options. Comprehensive policies are available that shield participants from the risks that accompany brownfields redevelopment. For example, there are policies which provide coverage for first-party liability (direct state or federal action against a potentially responsible party), third-party pollution legal liability (third-party lawsuits for damages caused to neighboring sites), and unexpected cost increases incurred during an approved site cleanup. Insurance policies can be transferred along with the property, further facilitating sales of brownfields properties.

The cost of insurance can be prohibitive, however. Here again, the participation of the public sector can play a critical role in expediting asset transfers. For example, the Massachusetts Brownfields Redevelopment Access to Capital Program provides environmental insurance for the developer and secured creditor coverage for the lender. The state-sponsored and subsidized environmental insurance is designed to protect the developer from cleanup cost overruns and from liability arising from newly discovered pre-existing environmental contamination. In addition, lenders can be protected from losses due to a default related to environmental issues. According to the Massachusetts' Governor's Office for Brownfields Revitalization, the state provides a subsidy of fifty percent of the insurance premium for most business projects; for a $\$ 5$ million project with cleanup costs of $\$ 1$ million, the costs of coverage can be as little as $\$ 15,000 .{ }^{13}$ 


\section{Innovative Financing Arrangements}

Innovative institutional arrangements are often needed as well to finance brownfields redevelopment projects. Local government tax incentives, such as Tax Increment Financing (TIF), may be applicable to the area in which the property is located; if not, the community can work with their local municipality to establish a TIF zone that includes their parcel. ${ }^{14}$ Community Development Block Grants and Section 108 funds, both of the Department of Housing and Urban Development (HUD), have been increasingly applied to brownfields redevelopment projects. HUD also targets monies specifically to brownfields projects through its Brownfields Economic Development Initiative grants. State and local financial support may also be available. New Jersey, for instance, offers Smart Growth Planning Grants to municipalities to encourage redevelopment and sustainable use of land resources, and to discourage sprawl in suburban and rural areas. Other potential sources of support include Empowerment Zone funds (if the community is in an Empowerment Zone), EPA pilot project grants, Local Initiative Support Council loans, and federal agencies such as the Economic Development Agency.

Brownfields funding is a complex business, and projects typically must cobble together a number of funding resources, from federal, state, and local agencies as well as private investment from developers and end users. This task may be beyond the experience and capacity of the local municipality or CDC, in addition to being very time consuming. The expertise of brownfields intermediaries can be particularly helpful at this juncture. A number of non-profit and for-profit organizations have emerged in recent years to provide financing, mediation, remediation, and technical services to brownfields stakeholders. ${ }^{15}$

\section{Conclusion}

The redevelopment of contaminated properties is a complex, time-consuming, and often frustrating experience. There is no avoiding the fact that it is simply easier and, at least in the short run, cheaper to develop uncontaminated properties. Even for the most enthusiastic advocates of brownfields redevelopment, some projects fail to live up to their economic and community-building expectations.

Yet the examples of successful community participation discussed above illustrate some of the innovative strategies and effective partnerships which hold promise for successful brownfields redevelopment. When the owners of brownfields sites are persuaded to take responsibility for their deleterious effect on the surrounding community; when the public sector provides the incentives and support that the market cannot; when the stakeholders work in a committed and cooperative fashion; and when communities organize effectively so as to claim their rightful share in ownership of the redevelopment process

and its outcomes - then and only then can brownfields be transformed from corporate liabilities to community assets which truly benefit the often poor and predominantly minority residents in their host neighborhoods. 


\section{Endnotes}

${ }^{1}$ Superfund sites - those listed on EPA's National Priorities List-are excluded from the EPA definition of brownfields.

2 These amendments are known as the Asset Conservation, Lender Liability, and Deposit Insurance Protection Act of 1996, signed into law by President Clinton as part of the 1997 appropriations bill.

3 According to the EPA's Brownfields Mission Statement, the 'EPA's Brownfields Initiative will empower States, communities, and other stakeholders in economic development to work together in a timely manner to prevent, assess, safely clean up, and sustainably reuse brownfields." For more information on EPA's brownfields programs, see the EPA Office of Solid Waste and Emergency Response website, at http://www.epa.gov/swerosps/bf/.

${ }^{4}$ Only publicly owned sites are eligible for EPA pilot grants.

${ }^{5}$ For an in-depth analysis of this and other brownfields case studies, see The Heldrich Center for Workforce Development, "Turning Brownfields Into Jobfields: Selected Brownfields Case Studies, 12/99" at http://www.heldrich.rutgers.edu.

${ }^{6}$ One example of this cooperative relationship is an agreement by which the developer is required to meet with local citizens twice annually for 20 years to address residents' concerns and grievances.

${ }^{7}$ When engaging in long-term planning, some parcels will be developed later than others. It may be tempting for some stakeholders (such as the public sector) to want to use these parcels "temporarily" for uses other than those for which they were intended. Storage is an example of such an interim use. Such uses are discouraged in order to avoid the permanent establishment of activities that are not compatible with the community's vision.

8 The local community knew that there would be some daunting obstacles to overcome before their vision for the neighborhood could become realized. First and foremost, who would pay for the cleanup and redevelopment of the site? LTV, while still subject to federal and third party liability, would not be a source of funding. At the same time, the city of Pittsburgh has an extensive redevelopment agenda, and nobody knew how much money and resources the city would commit to the LTV site. Eventually the city decided to buy the site with the understanding that it would work with a developer to have the site assessed and remediated. Second, there were infrastructure and real estate problems. Part of the site is located in a 100-year flood plain, and any redevelopment in this area would require careful planning. Also, the foundation of the former steel mill remained buried on site, and would have to be removed or built over. Third, local residents were concerned about increased traffic and congestion that would result from redevelopment. Railroad 
tracks crisscross the site, creating railway easement issues. In addition, structural problems existed with the bridges in the local area that span the Monongahela, compromising access to the area and contributing to traffic congestion. Finally, when the city began to develop its own plans for the site, those plans clashed harshly with the community's redevelopment vision: in 1992, the URA entered into an agreement to bring riverboat casino gambling to the area, contingent upon state legislative action legalizing gambling. This plan was eventually abandoned in the face of vociferous public opposition.

${ }^{9}$ Although LTV Steel was released from state liability at the site, the firm still could be held liable in a federal or third party action.

10 For a history of the Dudley Street Neighborhood Initiative, and information on its activities, see the Dudley Street Neighborhood Initiative Homepage at http://www.dsni.org/contents.htm. See also Medoff and Sklar (1994).

11 At least one brownfields intermediary, the Chicago Land Redevelopment Institute (REDI) is exploring the option of serving as an indemnifier in the case of mothballed properties in order to encourage their transfer.

12 Regulations regarding the cleanup of contaminated sites varies from state to state. Most states have a Voluntary Cleanup Program that offers site owners release from state liability, usually in the form of a No Further Action letter or Covenant Not To Sue, provided the cleanup is done in accordance with state cleanup laws. This does not remove the threat of federal liability, although EPA generally respects state VCP agreements and rarely takes action against such sites. In addition, many state VCPs include technical assistance and financial resources.

13 For more information on the Brownfields Redevelopment Access to Capital Program, see the Massachusetts Governor's Office for Brownfields Revitalization, at http://www.state.ma.us/.

14 Tax Increment Financing is a redevelopment strategy that uses tax revenue growth produced by an increase in the tax base of a specified area to repay the costs of investment in the area. It is created through a local government's assessment of property values. Special assessments are made on properties that are expected to accrue particular benefits from general improvement, or from an environmental activity such as brownfields cleanup. The incremental difference in tax revenues between the original assessment rate and the new, higher rate is then used by the local government to help the private sector pay for the improvement activity. Many cities and redevelopment authorities use TIF to encourage the private sector to redevelopment contaminated or blighted areas.

15 Examples of non-profit organizations include the Phoenix Land Recycling Company, the Development Fund, and the California Center for Land Recycling. 


\section{References}

Bailey, Connor, Kelly Alley, Charles E. Faupel, and Cathy Solheim. 1995. "Environmental Justice and the Professional." In Environmental Justice: Issues, Policies, and Solutions, edited by Bunyon Bryant. Washington, DC: Island Press.

Chess, Caron. 1999. "Evaluating Environmental Public Participation: Methodological Questions." New Brunswick, NJ: Center for Environmental Communications. Unpublished paper.

Clarke, Susan E., and Gaile, Gary L. 1995. "The Next Wave: Postfederal Local Economic Development Strategies." In Exploring Urban America, edited by Roger W. Caves. Thousand Oaks, CA: Sage Publications, Inc.

Dalton, Kathy L. 1998. Reclaiming Lost Ground: A Resource Guide for Community Based Brownfields Development in Massachusetts. Boston, MA: Environment and Community Development Program, Lincoln Filene Center, Tufts University. Accessed at http://www.dsni.org/reclaiming_lost_ground.htm.

Davis, Annie. 1999. Interview by author. Birmingham, Alabama, 17 February.

Doogan, Paula. 1998. Working on Brownfields: The Employment and Training Connection. Washington, DC: Northeast-Midwest Institute.

Dudley Street Neighborhood Initiative. 2000. "Mission Statement." Available at http://www.dsni.org/contents.htm.

Environmental Protection Agency (EPA). 1997. Office of Solid Waste and Emergency Response, "Brownfields Glossary of Terms," p. 3. Available at http://www.epa.gov/swerosps/bf/glossary.htm\#brow, last updated on 9.30.97.

General Accounting Office. 1987. Superfund: Extent of Nation's Potential Hazardous Waste Problem Still Unknown. Washington: U.S. Government Printing Office.

Greenberg, Michael, and Karen Lowrie, Laura Solitare, and Latoya Duncan. 1999. "Brownfields, TOADS and the Struggle for Neighborhood Redevelopment: A Case Study of the State of New Jersey." New Brunswick, NJ: Center for Neighborhood and Brownfields Redevelopment.

Jezierski, Louise. 1995. "Neighborhood and Public-Private Partnerships in Pittsburgh." In Exploring Urban America, edited by Roger W. Caves. Thousand Oaks, CA: Sage Publications, Inc.

Knezevich, Marc. 1999. Telephone interview by author. 2 January. 
Krumholz, Norman. 1995. "Equity and Local Economic Development." In Exploring Urban America, edited by Roger W. Caves. Thousand Oaks, CA: Sage Publications, Inc.

Mallach, Allan. 1998. "Rebuilding Urban Neighborhoods: Thinking About Brownfields Sites in the Context of Neighborhood Revitalization and Redevelopment." Paper presented to the Environmental and Occupational Health Institute, Workshop on Redefining Public Health for Brownfields Neighborhoods. New Brunswick, NJ (December 11, 1998).

Medoff, Peter and Holly Sklar. 1994. Streets of Hope: The Fall and Rise of an Urban Neighborhood. Boston: South End Press.

Pepper, Edith. 1996. Lessons from the Field. Washington, DC: Northeast-Midwest Institute.

Sherraden, Michael. 1991. Assets and the Poor: A New American Welfare Policy. Armonk, New York: M.E. Sharpe, Inc.

Urban Redevelopment Authority of Pittsburgh, 1999, "LTV Southside Works Fact Sheet."

Van Horn, Carl, K. A. Dixon, Gregory Lawler, and Daniel Segal. 1999. Turning Brownfields Into Jobfields: A Handbook for Practitioners and Citizens on Making Brownfields Development Work. New Brunswick, NJ: The John J. Heldrich Center for Workforce Development, Rutgers, the State University of New Jersey.

Vig, Norman J. and Michael E. Kraft, eds. 1999., Environmental Policy, Washington, DC: CQ Press.

Wallsjasper, Jay. 1997. "When Activists Win: The Renaissance of Dudley St." 


\section{The Author}

K. A. Dixon is a Project Director at the John J. Heldrich Center for Workforce Development at Rutgers University. The Heldrich Center provides an independent source of analysis for reform and innovation in policy making, and employs research and evaluation projects to identify best practices in workforce development, employment, and workplace policy. It also engages in partnerships with the private sector to design effective education and training programs, and it assists job seekers and workers to attain the information, education, and training they need to move up the economic ladder.

Dixon coordinates the Center's work on brownfields redevelopment, transportation planning and telecommunications, and other projects related to environmental aspects of workforce and economic development. She is co-author of the Heldrich Center's national study published for the Ford Foundation, Turning Brownfields into Jobfields, which focuses on the job-creating and community-building potential of the redevelopment of environmentally impaired properties. She previously worked in environmental law as a legal assistant on matters relating to the Superfund, toxic torts, and brownfields.

Dixon graduated with honors from Cook College at Rutgers University with a degree in Environmental Studies and Political Science. She is currently pursuing a Masters of Public Policy (MPP) at the Bloustein School at Rutgers.

\section{The Natural Assets Project}

The Natural Assets Project, based at the Political Economy Research Institute of the University of Massachusetts, Amherst, is a collaborative initiative launched with support from the Ford Foundation. The project aims to promote critical analysis and discussion of the potential for building natural assets - individual and social wealth based on natural resources and ecosystem services - to advance the goals of poverty reduction, environmental protection, and environmental justice. 